\title{
UV Electron Photo-Detachment Dissociation Of DNA Polyanions \\ In a Quadrupole Ion Trap Mass Spectrometer
}

Valérie Gabelica $^{1 *}$, Thibault Tabarin ${ }^{2}$, Frédéric Rosu ${ }^{1}$, Rodolphe Antoine ${ }^{2}$, Isabelle Compagnon ${ }^{2}$, Michel Broyer ${ }^{2}$, Edwin De Pauw $^{1}$, Philippe Dugourd ${ }^{2 *}$

(1) Laboratoire de Spectrométrie de Masse, Université de Liège, Institut de Chimie, Bat B6c, B4000 Liège, Belgium, and (2) Laboratoire de Spectrométrie Ionique et Moléculaire, UMR 5579 CNRS et Université Lyon 1, 43 Bd du 11 Novembre, F-69622 Villeurbanne, France.

\section{Supporting information:}

- Figure S-1: Sequence coverage in EPD on ssB (5'-CGCGAATTCGCG-3').

- Figure S-2: Sequence coverage in EPD on SsD (5'-CCAGGACGCCTCAGA-3' ). 

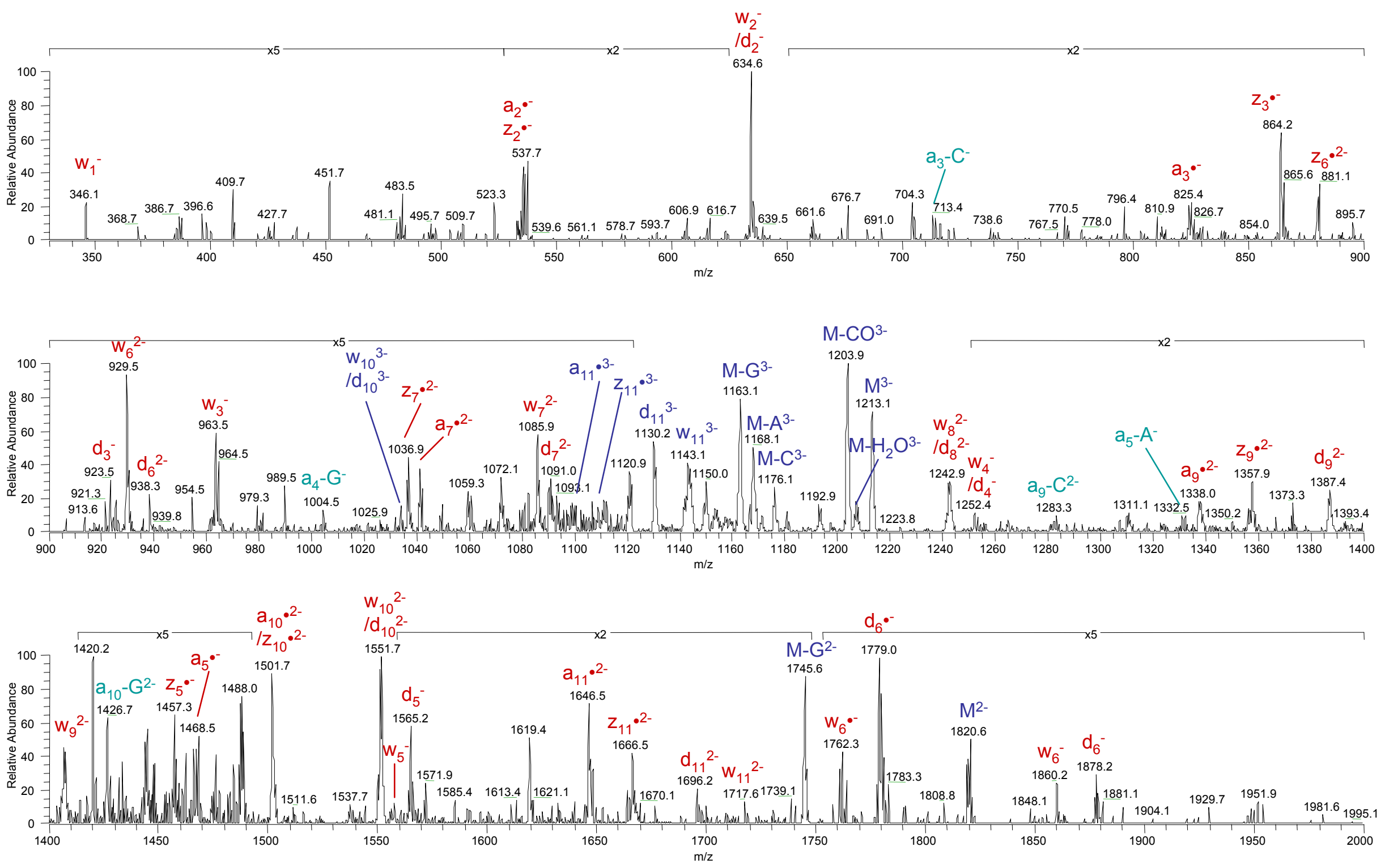

Figure S-1: Sequence coverage in EPD on SSB: CID (30 ms, varied activation amplitude) on $[\mathrm{ssB}-4 \mathrm{H}]^{\bullet-3-}$ produced by electron photo-detachment of [ssB-4H] $]^{4-}$ under $2 \mathrm{~s}$ irradiation at $260 \mathrm{~nm}$. 

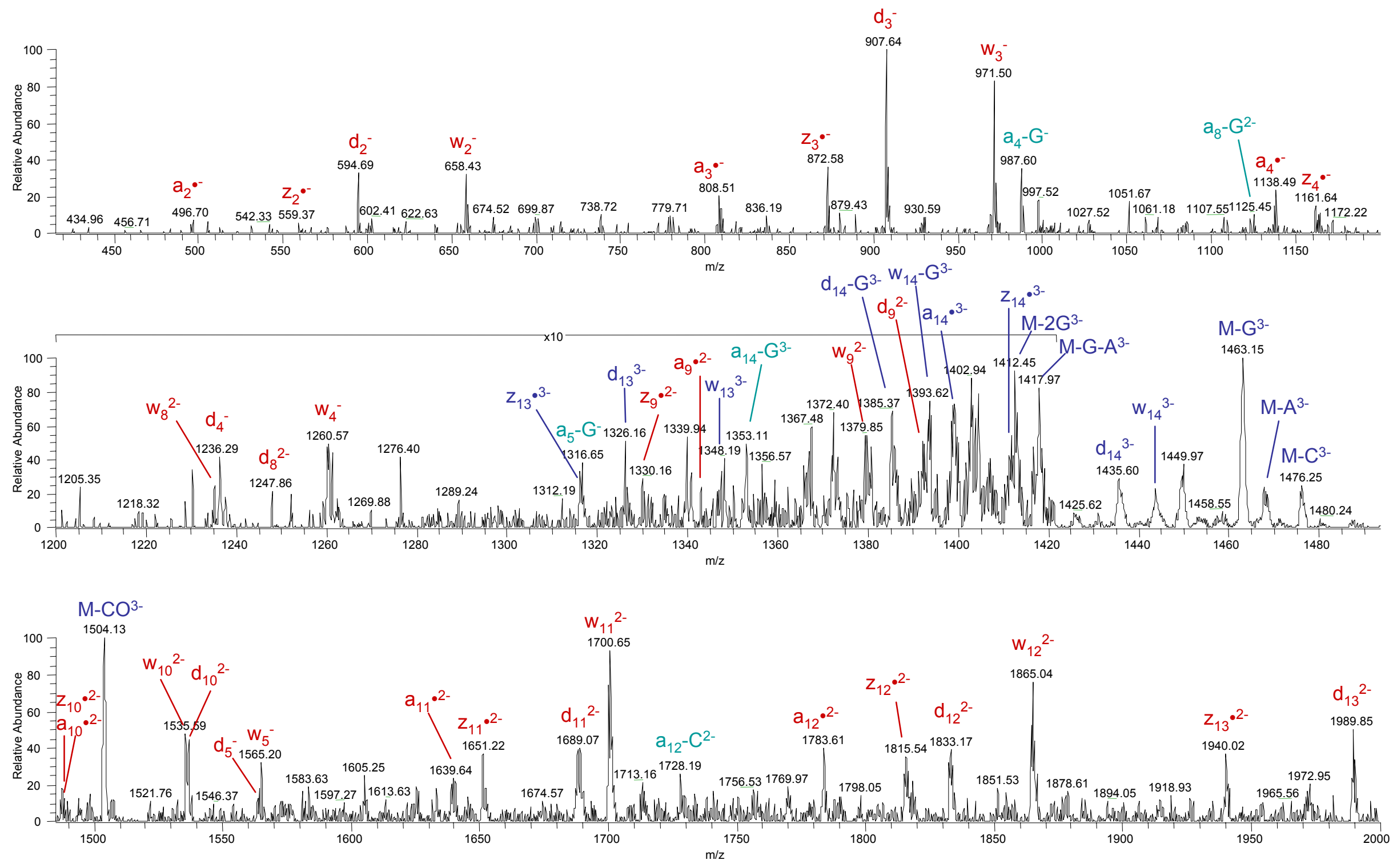

Figure S-2: Sequence coverage in EPD on SsD: CID (30 ms, varied activation amplitude) on $[\mathrm{ssD}-4 \mathrm{H}]^{\bullet-}$ produced by electron photo-detachment of [ssD-4H] $]^{4-}$ under $2 \mathrm{~s}$ irradiation at $260 \mathrm{~nm}$. 